\title{
VOMITING, REGURGITATION AND ASPIRATION \\ IN ANAESTHESIA, I.
}

\section{Brian M. Marshall, M D., and R. A Gordon, B SC, M D , D A , F R C P (C), F.F.A.R.C S. ${ }^{1}$}

ThE SERIOUS NATURE of pulmonary complications following general anaesthesia has long been recognized and has gained a prominent position in medical literature. Since the earliest writngs authors have agreed that aspiration is an important factor in the aetıology, but there has been a lack of agreement on other points between earlier authors and present-day investigators.

Holscher (1) in 1898 drew the following conclusions based on observations made after ether anaesthesia: (1) Tracheal rales are due to aspiration of mouth secretions while under anaesthesia, and can be avouded by proper technique. (2): Most lung infections after anaesthesia are due to aspiration of secretions from the mouth Support for this theory was given in 1926 by W. S Lemon (2) who published experimental evidence to show that aspuration of mouth contents during anaesthesia was the cause of postoperative pulmonary complications. $\mathrm{He}$ anaesthetized (or ethenzed) unpremedicated dogs, and slowly poured radiopaque or indicator substance into the mouth of the dog In all dogs, except those anaesthetized in the Trendelenburg position, the substance was detected in the chest by X-ray and was recovered at necropsy in the smallest bronchi

The pathological picture of "aspiration pneumonia" was discussed by Apfelbach and Christiansen(3) in 1937 and further by Apfelbach and Irons (4) in 1940. The first paper described the sequelae of flooding the respiratory tract with stomach contents while under anaesthesia. The resulting pathological changes in the lungs were haemolysis, oedema, haemorrhage, acute emphysema, and necrosis. Commenting on this report, Dr. M. W. Binger of Rochester, Minnesota, referred to a survey of postoperative pneumonia made in 1926-7 by himself and Dr. Wilder, and stated that "most were aspiration pneumonia because of the finding of haemolytic streptococci and food particles in the lung." The paper of Apfelbach and Irons described the pathological finding at greater length These authors found the condition more frequently in cases of coma and acute bowel obstruction, and reported that 36 of 150 necropsies showed criteria of aspiration pneumonia Bowel obstruction and upper gastro-intestınal surgery were most frequently anvolved. Hiccoughs and eructations, were more commonly a causative factor than was frank vomiting.

In 1946 C. L. Mendelson (5) reported on "Aspiration of Stomach Contents into the Lungs during Obstetrical Anaesthesia." This paper is considered by many as the classic work on the "aspiration syndrome," which has sometumes been referred to as "Mendelson's Syndrome" Mendelson reviewed 66 occurrences of aspiration of stomach contents in 44,016 pregnancies. Of these 45 were recognized dunng anaesthesia, 5 of these patients aspurated solid food, of whom 2 died, 6 of the 45 had lung complications, one being a lung abscess. The cases were grouped as falling distinctly into the categores of aspiration of solid or of hquid material. In the first there was laryngeal or bronchial obstruction which

1Department of Anaesthesia, University of Toronto, and Toronto General Hospital 
was relieved when the obstruction was removed. The clnical picture was atelectasis, pulmonary collapse, mediastinal shift, cyanosis, dyspnoea and tachycardia. The second group (liquid material) presented as an "asthmatic like syndrome" with dyspnoea, cyanosis, tachycardıa, and a typical X-ray picture of diffusely scattered soft mottled densities. This type progressed to cardiac embarrassment-and pulmonary oedema. Clinical improvement in twenty-four to thurty-six hours was usual with clearing of the X-ray in seven to ten days.

Mendelson was able to reproduce this clinical picture in experimental animals using $\mathrm{N} / 10 \mathrm{HCl}$ or sterilized liquid vomitus. There was no reaction produced when neutralized hqud vomitus or normal saline was the aspirated fluid The pathological picture described was an injected trachea filled with pink frothy material, pleural effusion, and sub-pleural haemorrhages. The lung parenchyma showed scattered areas of emphysema. The heart was dilated and there was congestion of the abdominal viscera. The microscopic picture was one of congestion of the trachea and large bronchi, spasm of the bronchioles, with haemorrhage and exudate The alveolar walls were necrotic. There was, perivascular oedema as well as generalized oedema and congestion of the lung parenchyma. Mendelson stressed prevention as the wisest method of treatment, and recommended withholding food and fluid from patients during labour, careful selection of anaesthetic method, and neutralization of gastric contents.

Merrill and Hingson (6) in 1951 quoted figures from 2,500,000 births in 183 hospitals in the United States of America and stated that 1.5 to 25 per cent of maternal mor ality resulted from aspiration. Edwards, Morton, Park, and Wylie (7) publishec a survey of 1,000 deaths associated with anaesthesia reported to them in the 5-year period ending in 1955 They stated that 11 per cent of deaths were caused by aspiration, of which 10 per cent were aspiration of solid food. Of the 110 cases 15 were obstetrical, 14 being emergency procedures

Culver, Makel and Beecher (8) published a study of the frequency of aspiration of stomach contents during surgical anaesthesia. Evans blue dye was given 30 minutes preoperatıvely to 300 unselected surgical patients. Its presence in the pharynx or trachea and brcnchi was taken to be evidence of regurgitation or aspuration It was found that 26 per cent of patients had regurgitated and 16 per cent had aspirated into the lungs Frank vomitng occurred in 8 per cent of cases and silent aspiration occurned in 8 per cent W A Weiss (9) published a similar study, using the same method of investigation, with similar results. Contributing factors mentioned by both authors were. position of the patient, the conduct of anaesthesia, the nature of the surgical procedure, and the presence of a duodenal tube.

H F. Chase (10) published a report of studies of the delayed gastric emptying time of experimental anımals which had received various combinations of drugs. His work showed that the gastric emptying time was doubled in those animals which received a normal preoperative dose of a narcotic plus one of the belladonna alkaloıds

E. J. O'Mullane (11) investigated the action of the cardiac sphincter and the pharyngeal and oesophageal muscles and drew the following conclusions. (1) The cardiac sphincter acts as a ball valve, which normally will withstand high pressures It is not affected by curare, autonomic nervous system block, or 
local anaesthetic agents. (2) The crico-pharyngeal sphincter prevents access to the oesophagus more than reflux from the oesophagus to the pharynx. (3) The cardiac sphincter is made incompetent by a distended stomach, or by obstruction to inspiration. (4) Material in the oesophagus will regurgitate into the pharynx in deep anaesthesia, with muscle relaxation, or when there is a pressure gradient between the oesophagus and the pharynix.

In 1957 a study was made at the Toronto General Hospital to determine the incidence of vomiting, regurgitation, and aspiration into the lung in patients under general anaesthesia. Two hundred and nineteen consecutıve general surgical and obstetrical patients were given Evans blue dye $10 \mathrm{mg}$. by capsule, or in suspension via a duodenal tube, thirty minutes prior to operation or dehvery. At the end of the anaesthetic the pharynx, and whenever possible the trachea, were examined for Evans blue dye. The method of study was effective but not without comment from the nursing and professional staff

From Table I it can be seen that of 219 patients, 36 had evidence of vomiting, regurgitation, or aspiration during or immediately after anaesthesia. Of these, 11 patients gave no clue to the anaesthetist that anything untoward was happening. It is of interest that the gieatest incidence was in obstetrical patients

TABLE I

\begin{tabular}{|c|c|c|c|c|c|c|}
\hline \multirow{2}{*}{$\begin{array}{c}\begin{array}{c}\text { Type of } \\
\text { operation }\end{array} \\
\text { Obstetrical }\end{array}$} & \multirow{2}{*}{$\begin{array}{c}\begin{array}{c}\text { Number } \\
\text { of patients }\end{array} \\
58\end{array}$} & \multirow{2}{*}{$\begin{array}{c}\begin{array}{c}\text { Vomited } \\
\text { post anaesthetic }\end{array} \\
11\end{array}$} & \multicolumn{2}{|c|}{ Regurgitated } & \multicolumn{2}{|c|}{$\frac{\text { Aspurated }}{\text { Silent Obvious }}$} \\
\hline & & & 4 & 1 & 0 & 1 \\
\hline Gynaecology & 50 & 2 & 0 & $\overline{0}$ & 0 & 0 \\
\hline General Surgery $\nmid$ & 84 & 2 & 5 & 0 & 0 & 0 \\
\hline Laparotomy & 27 & 1 & 1 & 1 & 1 & 0 \\
\hline TotaL & 219 & 16 & 10 & 2 & 1 & 1 \\
\hline Percentage & & 7 & 5 & 1 & 05 & 05 \\
\hline
\end{tabular}

- Including Caesarean sections

$\uparrow$ Exclusive of laparotomies which are totalled separately

TABLE II

\begin{tabular}{|c|c|c|c|c|c|c|c|}
\hline Operation & Anaesthesia & Induction & $\begin{array}{l}\text { Main- } \\
\text { tenance }\end{array}$ & $\begin{array}{l}\text { Endo- } \\
\text { trach- } \\
\text { eal } \\
\text { tube }\end{array}$ & $\begin{array}{l}\text { Duo- } \\
\text { denal } \\
\text { tube }\end{array}$ & Position & Complication \\
\hline \multirow[t]{5}{*}{$\begin{array}{l}\text { Obstetrical } \\
\text { delivery }\end{array}$} & $\begin{array}{l}\text { Epidural } \\
\text { pluz } \mathrm{C}_{3} \mathrm{H}_{6}\end{array}$ & Smooth & $\begin{array}{l}\text { Smooth } \\
\text { Light }\end{array}$ & No & No & Lith & $\begin{array}{l}\text { Aspiration } \\
\text { post- } \\
\text { operatıvely }\end{array}$ \\
\hline & $\mathrm{C}_{3} \mathrm{H}_{6}$ & Smooth & $\begin{array}{l}\text { Smooth } \\
\text { Light }\end{array}$ & No & No & Lith & Regurgitated \\
\hline & $\mathrm{C}_{3} \mathrm{H}_{6}$ & Smooth & $\begin{array}{l}\text { Smooth } \\
\text { Deep }\end{array}$ & No & No & Lith & Regurgitated \\
\hline & $\mathrm{N}_{2} \mathrm{O} / \mathrm{O}_{2} \quad \mathrm{C}_{3} \mathrm{H}_{6}$ & Difficult & Deep & No & No & Lith & Regurgitated \\
\hline & $\begin{array}{l}\mathrm{N}_{2} \mathrm{O} \text { trichlorethy- } \\
\text { lene } \mathrm{O}_{2}\end{array}$ & $\begin{array}{l}\text { Difficult } \\
\text { Retching }\end{array}$ & $\begin{array}{l}\text { Light } \\
\text { Strainıng }\end{array}$ & No & No & Lith & Regurgitated \\
\hline
\end{tabular}


TABLE II (continued)

\begin{tabular}{|c|c|c|c|c|c|c|c|}
\hline Operation & Anaesthesia & Induction & $\begin{array}{c}\text { Mann- } \\
\text { tenance }\end{array}$ & $\begin{array}{l}\text { Endo- } \\
\text { trach- } \\
\text { eal } \\
\text { tube }\end{array}$ & $\begin{array}{l}\text { Dup- } \\
\text { denal } \\
\text { tube }\end{array}$ & Pos.tion & Complication \\
\hline $\begin{array}{l}\text { Caesarean } \\
\text { section }\end{array}$ & $\begin{array}{l}\text { Fpidural } \\
\text { Thropentone } \\
\mathrm{O}_{2}\end{array}$ & Smooth & $\begin{array}{l}\text { Light } \\
\text { Straining }\end{array}$ & No & No & $\begin{array}{l}\text { Trendel- } \\
\text { enburg }\end{array}$ & - Regurgitated \\
\hline $\begin{array}{l}\text { Burn. } \\
\text { dressing }\end{array}$ & & Smooth & $\begin{array}{l}\text { Smooth } \\
\text { Light }\end{array}$ & No & No & Surine & Regurgitated \\
\hline Tonsillectomy & $\begin{array}{l}\text { Thropentone } \\
\text { Succiny lcholine } \\
\mathrm{N}_{2} \mathrm{O} / \mathrm{O}_{2}\end{array}$ & Smooth & Smooth & $\begin{array}{l}\text { Naso- } \\
\text { tra- } \\
\text { cheal }\end{array}$ & No & Supine & Regurgitated \\
\hline Mastectomy & $\begin{array}{l}\text { Thiopentone } \\
\text { Meperidine } \\
\text { Succinylcholine } \\
\mathrm{N}_{2} \mathrm{O} / \mathrm{O}_{2} \\
\end{array}$ & Smooth & Light & $\begin{array}{l}\text { Oro- } \\
\text { trach- } \\
\text { eal }\end{array}$ & No & Supine & Regurgitated \\
\hline $\begin{array}{l}\text { I horacotomy } \\
\text { and } \\
\text { bronchoscopy }\end{array}$ & $\begin{array}{l}\text { Thiopentone } \\
\text { Succinylcholue } \\
\text { d-tubocurate } \\
\text { Meperidine } \\
\mathrm{N}_{2} \mathrm{O} / \mathrm{O}_{2} \\
\text { Controlled resp }\end{array}$ & Smooth & Light & $\begin{array}{l}\text { Oro- } \\
\text { trach- } \\
\text { eal }\end{array}$ & No & $\begin{array}{l}\mathrm{R} \\
\text { lateral }\end{array}$ & Regurgitated \\
\hline $\begin{array}{l}\text { Inguinal } \\
\text { hernia }\end{array}$ & $\begin{array}{l}\text { Thiopentone } \\
\text { d-tubocurare } \\
\mathrm{N}_{2} \mathrm{O} / \mathrm{O}_{2} \mathrm{C}_{3} \mathrm{H}_{6} \\
\end{array}$ & Smooth & Light & No & No & Stpine & Regurgitated \\
\hline $\begin{array}{l}\text { Appendiceal } \\
\text { abscess }\end{array}$ & $\begin{array}{l}\text { Thiopentone } \\
\text { d-tubocurare } \\
\mathrm{C}_{3} \mathrm{H}_{6}\end{array}$ & Smooth & Variable & $\mathrm{No}$ & No & Supine & Vomited \\
\hline $\begin{array}{l}\text { Thy roid- } \\
\text { ectomy }\end{array}$ & $\begin{array}{l}\text { Thropentone } \\
\text { Succiny loholine } \\
\text { decamethonum } \\
\mathrm{N} \mathrm{O}_{2} / \mathrm{O}_{2} \mathrm{C}_{3} \mathrm{H}_{6} \\
\end{array}$ & Smooth & Deep & Yes & No & $\begin{array}{l}\text { Head } \\
\text { up }\end{array}$ & Vomited \\
\hline $\begin{array}{l}\text { Colon } \\
\text { resection }\end{array}$ & $\begin{array}{l}\text { Thiopentone } \\
\text { Succinylcholine } \\
\text { d-tubocurare } \\
\mathrm{N}_{2} \mathrm{O} / \mathrm{O}_{2} \mathrm{C}_{3} \mathrm{H}_{6} \\
\text { Controlled res- } \\
\text { piration }\end{array}$ & Snooth & Deep & Yes & No & Supine & Aspirated \\
\hline $\mathrm{H}_{\searrow}$ sterectomy & $\begin{array}{l}\text { Epidural, } \\
\text { Thiopentone } \\
\text { Succinylcholine } \\
\text { d-tubocurare } \\
\mathrm{C}_{3} \mathrm{H}_{6} \\
\end{array}$ & Smooth & Light & Yes & No & $\begin{array}{l}\text { Trendel- } \\
\text { enburg }\end{array}$ & - Regurgitated \\
\hline $\begin{array}{l}\text { Bilateral } \\
\text { adrenal- } \\
\text { ectomy }\end{array}$ & $\begin{array}{l}\text { Thropentone } \\
\text { d-tubocurare } \\
\text { Meperidine- } \\
\mathrm{N}_{2} \mathrm{O} / \mathrm{O}_{2} \text { Con- } \\
\text { trolled respiratior }\end{array}$ & Smooth & Deep & Yes & $\mathrm{No}$ & Supine & Regurositated \\
\hline $\begin{array}{l}\text { Chole- } \\
\text { cy stectomy }\end{array}$ & $\left\{\begin{array}{l}\text { Thiopentone } \\
\text { d-tubocurare } \\
\mathrm{N}_{2} \mathrm{O} / \mathrm{O}_{2} \mathrm{C}_{3} \mathrm{H}_{6}\end{array}\right.$ & Smooth & Varıble & Yes & Yes & Supine & Vomited \\
\hline \multirow[t]{2}{*}{$D$ and $C$} & $\begin{array}{l}\text { Thiopentone } \\
\mathrm{N}_{2} \mathrm{O} / \mathrm{O}_{2} \mathrm{C}_{3} \mathrm{H}_{6}\end{array}$ & Smooth & Light & No & No & Lith & Vomited \\
\hline & $\begin{array}{l}\text { Thropentone } \\
\mathrm{N}_{2} \mathrm{O} / \mathrm{O}_{2} \mathrm{C}_{3} \mathrm{H}_{6}\end{array}$ & Smooth & Light & No & No & Lith & Vomited \\
\hline
\end{tabular}


Table II describes the conduct of the anaesthesia for those patients who aspirated or regurgitated.

\section{Discussion}

Culver, Makel, and Beecher (8), and also W A. Weiss (9), reported in their series that the incidence of regurgitation into the pharynx was 25 per cent. Weiss reported that 79 per cent of those who regurgitated also aspirated. Factors which these and other authors reported as being contributory to regurgitation included all phases of anaesthesia and surgery as well as the preoperative condition of the patient. A stormy induction and straming or belching during anaesthesia were' noted as causes of regurgitation. Upper abdominal surgery, Trendelenburg, lateral or prone position, manipulation of abdommal organs, and the $_{t}$ presence of a duodenal tube were surgical conditions mentioned as being contributory. A patient who was poorly prepared for operation or poorly attended in the post-anaesthetic period was stated to be in danger of regurgitating and aspirating. In this respect a dilated stomach was thought to be the greatest threat.

In our series we attempted to examine each of these factors From Table I it is obvious that the obstetrical patients, who are usually poorly prepared and more likely to have full stomachs, had by far the greatest incidence of vomiting and regurgitation. The administration of the anaesthetsc appeared to be a lesser factor in our series than in others. In none of the surgical cases was there a stormy induction or straining, to account for the regurgitation or aspiration This may be explained by the fact that our routune induction is a "sleep-dose" of thiopentone. The fact that the swallowing reflex may not have been contunuously abolished in the patients with "light" anaesthesia may have been a factor in the regurgitation.

The surgical factors contributing to aspiration were more difficult to assess. Each factor mentioned, Trendelenburg position, manipulation of abdominal organs, and insertion of a duodenal tube wast thought to have triggered regurgitation or aspiration. The group of patents undergoing upper abdommal surgery showed a much higher incidence of positive findings than other general surgery patients. A follow-up study was done on these patients and compared with a similar group of twenty years ago

Seventy-nine cases of upper abdominal surgery were followed postoperatively. Three patients had scattered rhonchi forty-elght hours postoperatively. Ope of these had a duodenal tube in situ during the operation The chest findings did not clear until the duodenal tube was removed one week postoperatively, suggesting that continual regurgitaton may have occurred about the duodenal tube. These findings were compared with seventy-one cases of upper abdominal surgery from July 1938 to June 1939. Of these patients, five were reported with collapse of basal segments of either or both lungs, and two had rales and rhonchi at both bases. In this latter group the anaesthesia in 76 per cent was spinal and in 21 per cent spinal plus supplement of ether, cyclopropane or nitrous oxide and 
oxygen. Three patients only had endotracheal tubes, two of the anaesthetics being ethyl chlonde and ether and the other a spinal plus endotracheal ether supplement. Of the recent group, seventy-four cases were done using a cuffed endotracheal tube and controlled respiration. The patients were induced with a "sleep dose" of thiopentone and then a relaxing dose of succinylcholme or decamethonium was used for intubation. A musclè-relaxing agent was used throughout for surgical relaxation and to and in keeping the patient apnoeic. The endotracheal tube was not removed until the patient's cough reflex returned and there was adequate return of function of the muscles of respiration. The pharynx and trachea were suctroned before the endotracheal tube was removed.

This technique was not developed specifically to reduce the incidence of regurgitation and aspiration, but it does elıminate most of the factors involved. There is a minimum of straining on induction and durnng the maintenance of anaesthesia. The trachea is protected by the endotracheal cuff from any material regurgitated into the pharynx Another preventive factor is the presence of a positive pressure gradient between the larynx and the pharynx and oesophagus when controlled respration is used None of these features was present in the anaesthetics given in the 1938-9 group. Whether or not the chest complications in this group were the result of aspiration cannot be determined. However, when aspiration was adequately guarded against, as in the recent groups, major chest complications did not occur.

\section{SUMMARY}

This paper presents a review of literature dealng with regurgitation and aspiration and reports a study of the incidence of regurgitation and aspiration in surgical and obstetrical anaesthesia The clinical and pathological findings are described and factors contributing to regurgitation and aspiration are discussed The anaesthetic factors are described and discussed with reference to the study made by the authors A comparison follow-up study of one group of patients with a high incidence of reguigitation and aspiratior is made with a similar group of patients anaesthetized twenty years ago A possible reason for the marked decrease in postoperative pulmonary complications is presented

A subsequent article will present case histores and discuss treatment and sequelae of aspiration during anaesthesia

\section{RÉSUMIÉ}

Dans la littérature la plus ancienne sur le sujet, ceux quı ont traité des complicatıons pulmónarres à Ja suite d'anesthésıe générale ont attribué, pour une part importante, la cause de ces complicatıons à l'aspiration dans les poumons de matéı iel venant des vores dıgestives Les auteurs ont passé en revue la littérature sur le sujet des régurgitations et de l'aspiratıon de débris alımentaires durant l'anesthés1e. En 1957, à Toronto General Hospital, on a fast une étude pour déterminer la fréquence des vomissements, des régurgitations et de l'aspıration 
de débris chez les malades sous anesthésie générale. Chez 219 malades consécutifs, candidats à la chirurgie générale ou à lobstétrique, on a donné aux malades, en capsules ou en suspension par un tube duodénal, 30 minutes avant l'opération ou l'accouchement, $10 \mathrm{mg}$. de teinture bleue Evans. Après l'anesthésie, afin de trouver de la teinture bleue Evans, on a examiné le pharynx et, quand il était possible, la trachée. Culver, Makel et Beecher (8) ont déjà décrit cette méthode.

Sur ce nombre de 219 malades, 36 ont fourni des sıgnes évidents de régurgitation et de vomissements au cours de l'anesthésie ou immédiatement après. Parmi ces derniers, 12 malades n'ont présenté à lanesthésiste aucun signe qu'il se passait quelquechose d'anormal. La chose est arrivée plus souvent en anesthésie obstétricale (Table I)

D'autres auteurs $(8,9)$ ont mentiohné un certain nombre de facteurs pouvant favoriser les régurgitations, entr'autres: une induction difficle, des efforts et des haut-le-cour durant l'anesthésie, la chirurgie abdominale haute, la position de Trendelenbourg, la position latérale ou ventrale, les manipulations des organes abdominaux et la présence d'un tube duodénal. On a consıdéré comme prédisposés à des régurgitations et à de l’ạspiration de débris ceux dont la préparation à l'opération avait été moins élaborée et dont la survelllance post-opératoire avait été moins attentive

Parmi les cas cités par les auteurs, on a tenu compte de tous ces facteurs Il est évident que, chez les malades en obstétrique, malades moins bien préparées à l'anesthésie ết plus exposées à avoir quelquechose dans l'estomac, il s'observe un nombre beaucoup plus grand de 'vomissements et de régurgitations Dans cette série de cas, l'administration de l'agent anesthésique semble être un facteur moins important ce qui peut être explıqué par le fait que l'induction de routıne, chez les malades de chirurgie générale, se fait par une dose anesthésique de thiopentone. On a l'impression que chàcun des facteurs survants peut avoir déclanché des régurgitations et des aspirations la position de Trendelenbourg, la mani julation des organes abdominaux et la mise en place d'un tube duodénal On a observé que les malades opérés dans la partue supérieure de l'abdomen présentaient des régurgitatıons plus fréquentes que ceux opérés en chrrurgie générale.

On a observé, au cours des suites opératoires, un groupe de 79 cas de chururgie abdominale haute et on a noté une fréquence de complıcations pulmonarres bien inférieure à celle qu'on avart obtenue pour un groupe semblable de malades observés entre juillet 1938 et jum 1939. Bien qu'il soit impossible de démontrer ces conclusions, les auteurs ont la conviction que le contrôle des aspirations par les méthodes actuelles d'anesthésie peut être responsable de la diminution de fréquence des complications pulmonaires. Pour le premier groupe de malades: $76 \%$ avaient eu une rachianesthésie et $21 \%$, une rachianesthésie complétée par de l'éther, du cyclopropane ou du protoxyde d'azote et de l'oxygène Dans ce groupe-là, on avait placé un tube dans la trachée à tross cas seulement. Dans le dernier groupe, on a placé un tube avec ballonnet dans la trachée et on a pratiqué une respiration contrôlée chez 74 malades, et ce tube n'a été enlevé que lorsque le málade avait des réflexes à la toux et que ses muscles respiratoires avaient repris leur tonus. On a pratiqué l'intubation en administrant une dose 
anesthésique de thiopentone et une dose apnéique de mýrésolutifs de sorte que l'induction se faisait sans effort et que la trachée était crotégée sans retard en gonflant le ballonnet du tube endotrachéal.

Dans un prochain article, nous rapporterons des cas et parlerons du traitement et des sequelles de l'aspiration de débris alimentaires dans les voies respiratoires.

\section{REFERENCES}

1 HoLscher, Experımentelle Untersuchungen uber die Entstehung der Erkankungen der Luftwege nach Aethernarkose Arch Klin Chir 57: 175 (1897).

2. Lemon, W. S. Aspiration. Arch. Surg 12187 (January, 1926).

3. Apfelbaich, C W., \& Christianson, $O$. $O$ Alterations in Respuratory Tract from Aspirated Vomitus ] A M A. 108. 503 (1937)

4. Affelbach, C W, \& Trons, E. E. Aspiration Bronchopneumonia. J A.M A. 115584 (1940).

5. Mendelson, C. L Aspiration of Stomach Contents into the Lungs durng Obstetric Anesthesia. Am. J. Obst \& Gynec 52 191, (Aug. 1946)

6. Merrill, R. B., \& Hingson, R A. Study of Incidence of Maternal Mortality from Aspiration of Vomitus durinj Anaesthesia Occurnng in Major Obstetnc Hospitals in United States Anesth \& Ana.g 30121 (May-June, 1951)

7. Edwards, G, Morton, JH I V, Pask, E A; \& WyLte, W. D Deaths Associated with Anaesthesia. Anaesthesia 11,194 (July, 1956).

8. Curver, MAKel \& BeEchęr. Frequency of Aspiration of Stomach Contents by Lungs dumng Anaesthesia and Surgery Ann Surg 133289 (1951)

9 Weiss, W fA. Regurgitation and Aspiration of Stomach Contents during Inhalation Anesthesia Anesthesiology 11102 (January, 1950)

10 Chase, H. F Role of Delayed Gastric Emptying Time in Etology of Aspiration Pneumonia Am J Obst \& Gynec. 56 673 (Oct, 1948)

11 O'MullaNe, E J. Voniting and Regurgitation durmg Anaesthesia Lancet 2661209 (June 12, 1954) 